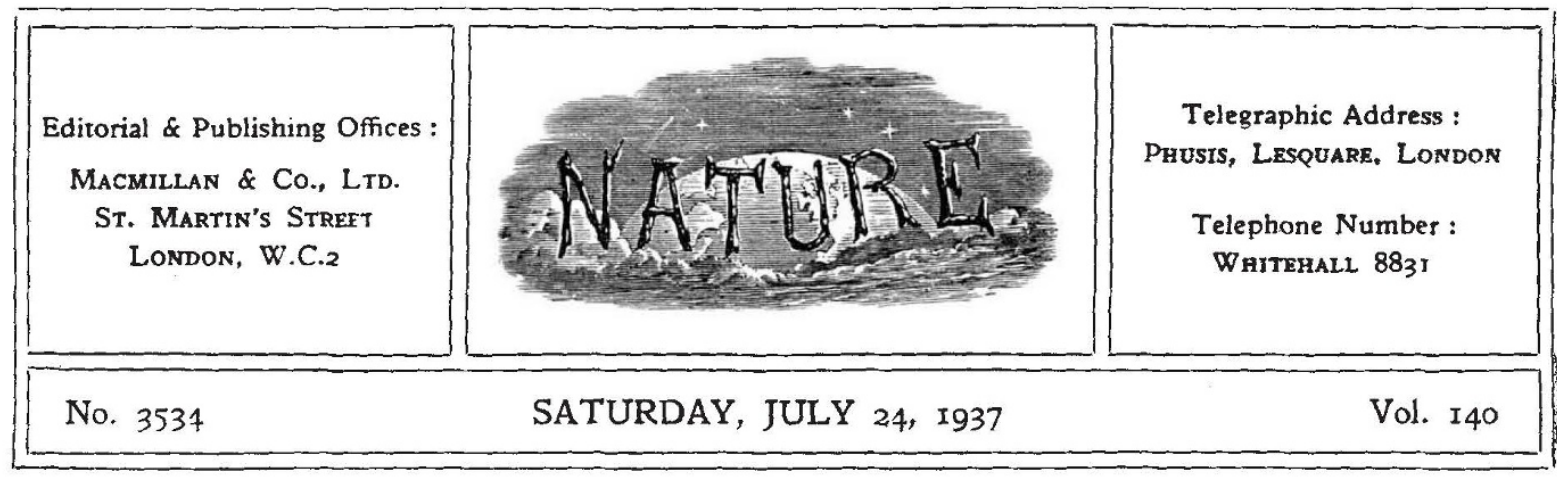

\title{
The Future of the South African Protectorates
}

$\mathrm{T}$ $\mathrm{HE}$ statement made by General Hertzog, Prime Minister of the Union of South Africa, on his return from attending the recent Imperial Conference in London, which dealt with the question of the transfer of administrative control of the South African native Protectorates to the Union (The Times, July 7), has raised a grave issue in the gravest possible manner. He accuses the British Government of a dilatoriness virtually amounting to bad faith, and in the event of further delay, foreshadows an appeal to the Crown, of which the consequences both to Great Britain and South Africa would be so incalculable, that he is not prepared to accept as final the British minister's reply to pressure for early transfer.

General Hertzog clearly intended a reply to certain opinions expressed in the House of Lords in the debate on Lord Noel Buxton's motion on June 9 (see Nature, June 26, p. 1083). When he went on to speak of the Government's attitude as dictated by the ballot box, he descended to a mere piece of political invective, worthy neither of its author nor of South Africa's case.

It cannot be denied that South Africa has a case ; and the interests of the Protectorates afford strong, indeed almost overwhelming, argument in support of that case on geographical, economic and administrative grounds. The territories are, and must always be dependent economically upon the Union. They have no natural effective outlet except through the Union; they are dependent upon it for the employment by which their labour makes up the deficiencies of their capacity to produce. On the side of the Union any serious disparity in administrative methods might at any moment aggravate difficulties in dealing with its own native question. Nor should it be overlooked that the Union has been generous in assistance to the Protectorates in a time of stress, although that assistance may have been granted under a misapprehension, for which General Hertzog himself is largely responsible.

Mr. Malcolm MacDonald, the Secretary of State for Dominion Affairs, showed in the House of Commons on July 9 that there had been a complete misunderstanding of the position. There had been no undertaking that transfer would be effected within any specified period. Once more he enunciated in terms the pledge, which was again repeated in the House on July 13, that no action would be taken without previous consultation of the inhabitants of the Protectorates, white and native, though he could not be brought to the point of a categorical statement that without consent there would be no action.

In delaying transfer, the British Government has displayed supreme wisdom. In the eyes of informed opinion-and in this matter the House of Lords is perhaps a better gauge of public feeling than the House of Commons, hence General Hertzog's aggrieved reference to its periodical pronouncements-the time is not yet ripe. For this the attitude of the Union Government on the native question is as much, if not even more responsible than the admitted reluctance of the Protectorate native populations to acquiesce in the change of administrative rule.

Since the passing of the South Africa Act of 1909, a great change in outlook has taken place in matters affecting the welfare and the administration of the affairs of backward peoples. At that time the anthropologist was urging the imperative necessity for scientific study of native institutions and beliefs as a basis for sympathetic administration. 
of native affairs. In South Africa the Government had embarked on a policy which seemed to hold out to the native an avenue of approach to a useful participation in citizenship and a share in the future development of the country through the organization of native councils. Great Britain, therefore, at that time felt justified in looking forward to a day when all the natives of South Africa might pass to South African control. Events in the political, economic and industrial history of the Commonwealth have falsified anticipation. The problem of the native population, which as a sociological question should be approached in the spirit of scientific and objective inquiry, has become an issue in party politics, while the trend of legislation, notwithstanding pledges to initiate a more liberal course of action when once the 'menace' of the native franchise was removed, has been to strengthen the colour bar and to emphasize the social and economic disability of the 'inferior' race, through the policy of segregation. It is not the least disquieting feature of the present situation that a certain section of advanced native opinion is strongly in favour of segregation and the complete separation of the two races in the interests of the native himself.

As a self-governing Dominion, it is South Africa's business to deal with her native problem as seems to her best. A white population outnumbered by the native in the proportion of four to one has need of provident statesmanship if it is to preserve its supremacy without crippling its powers of expansion. There is, however, in South Africa a growing section of opinion, in which the anthropological school of thought counts for much, that sees in the present policy of segregation as enforced by legislation, no way out for the native towards further development. In present conditions, it is true, some measure of training in various directions, educational and vocational, lies open to the native, though these conditions are perhaps less favourable than they were a generation ago. But there is little scope for the exercise of the native's powers and energy when once he is trained. For this impasse; the anthropologist would seek to substitute conditions such as a scientific and dispassionate survey of the situation would suggest. These, he is confident from his knowledge and experience, would, without turning the native into a black European, open the way to growth along lines congenial to native character and institutions, and yet would admit him to a share in the development of the country, to the advantage of white and native communities alike.

These matters, however, are for the Union of South Africa to decide; but the appearance within the Union of a body of opinion critical of the dominant policy is not without its lesson for the people of Britain. Under the Imperial Parliament, the policy of native administration has virtually ceased to be a political issue. In general, parties are now united in accepting the doctrine of 'trusteeship' as the principle of government of the backward peoples of the Empire; and that in appropriate circumstances, "the interests of the native shall be paramount", has been enunciated repeatedly as the decisive formula of British native administration. In the South African Protectorates under the administration of British officials, circumstances have brought about a system of control, which if not technically 'indirect rule', approaches that method of government in some near degree. Under that system, a process of acculturation has been taking place, which is producing a system of religious belief and social organization, that if neither entirely European nor wholly African, has something of each, and yetand this is the important factor-is both congenial to the African temperament and affords, in the eyes of competent judges, a potentiality of further cultural development along progressive lines. What those lines should be, it is the opportunity and the obligation of scientific study to assist in determining in the light of the effects of the cultural impacts which are now taking place-in short, the function of the 'applied anthropology' for which the Royal Anthropological Institute has recently appointed a standing committee (see p. 145).

Apart from the question of the obligation imposed on the Imperial Government by its pledge to consult the inhabitants of the Protectorates before any action is taken in the matter of the transfer of their administration to the Union, the crux of the problem lies in the temper with which the people of the Union of South Africa attempt to solve the problem of their own native population. Unless this is such as to afford a reasonable guarantee that it will foster rather than frustrate the steps, slow and hesitant they may be, now being taken by the natives of the Protectorates towards a cultural development, which may truly be regarded as a progress in civilization, the British Government should see no alternative but to hold its hand. 